\title{
The Relevance of Erau Tradition Values toward Character Building Values
}

\author{
Lailatul Khuriyah ${ }^{1,2}$, Sugeng Utaya ${ }^{2}$, \& Ari Sapto $^{2}$ \\ ${ }^{1}$ Student of Pascasarjana State University of Malang. Teacher of Junior High School 2 Karangan, East Kutai, \\ East Kalimantan, Indonesia \\ 2 Pascasarjana State University of Malang, Indonesia \\ Correspondence: Lailatul Khuriyah, SMP Negeri 2 Karangan, Kutai Timur, Kalimantan Timur, Indonesia. Tel: \\ 0823-5344-9504. E-mail: lailatulkhuriyah@gmail.com
}

Received: March 21, 2017

Accepted: April 12, 2017 Online Published: May 31, 2017

doi:10.5539/ass.v13n6p102

URL: https://doi.org/10.5539/ass.v13n6p102

\begin{abstract}
A culture has an important in for the development of the character of the young generation, because in the culture of each ethnic group has values that guide the society. The Erau Tradition of Kutai contains values in any rituals. This value can be a guideline for cultivation the character building and to minimize degradation and the eroded values of national identity in our youth. This study aims to: 1) know the values contained in Erau tradition, 2) know the relevance of traditional values of Erau with the values of Indonesian nation character education. The research was conducted in Kutai Kertanegara using ethnography approach. Erau tradition which made cooperation between the palace, local governments and communities indicates that this tradition contains religious values, unity, cooperation/cooperativeness, tolerance, social awareness, recognize excellence, democracy, work ethic, and the preservation of culture. These values has relevance to the educational value of the character of the Indonesian nation, although not in its entirety but these values are positive and capable of being used as a source of value for the community guidelines. With that understanding, the expected values may play a role in shaping the character of the nation.
\end{abstract}

Keywords: Erau, tradition, value, character education

\section{Introduction}

Nowadays, a lot of moral degradation phenomenon and the characters on the younger generation. This condition causes a shift in the values of national identity and moral damage which results in the life of society, nation and state. Suparno (2016), said that there are some appalling conditions experienced by our generation, among others: (1) the crime by the perpetrator of various ages, (2) Drugs, chronic targeting early childhood, (3) Promiscuity, combined with drugs and alcohol, (4) negative impact hobbies, staying up not know the time, a motorcycle gang, (5) Saxon extreme, and (6) Mental fighting low, like a shortcut.

Shifting values of national identity in our young generation are going one reason is the influx of foreign culture freely and without a proper filter. It is also exacerbated by changes in culture, western and other countries that have penetrated the lives of our people. The challenges of life, modernization and technological development was not only a positive impact on the life of society, but also gave birth to the negative impact of the weakening of the local cultural wisdom. This resulted in the growth of behaviors that were inappropriate and contrary to the dignity of the nation, and can be detrimental to the existence of cultural values of the nation

The inculcation of Nation's cultural values is one of the efforts in tackling and to overcome the aforementioned issue. Each culture from each ethnic group has the positive values that are able to serve as guidelines and solutions for the problems of such community. Alwasilah, Suryadi, and Karyono (2009:50) states that indigenous peoples/communities have been basically carrying out the tradition education (etnodidaktik) that includes the moral and character education. Traditional education is effective in providing educational practices for the community. For example the environment conservation education at Kampung Naga and Baduy indigenous communities. Similarly delivered by Musanna (2011: 588) which states that there is a belief in each community, has the techniques and strategies which serve as the basis to carry out activities in social life, pursuant to the context of their life, became the basis of educational development ideas, based on local wisdom. In addition, 
there is a belief that modern life does not guarantee the authentic happiness because it resulted in eroded spirituality and wisdom which also causes an imbalance of human interaction with fellow human beings and the environment.

This conditions and beliefs are what gave rise to the passion, to make local wisdom as a foothold in enriching the educational praxis. Character education in schools is a vital necessity in order that the next generation is not only equipped with basic capabilities as learners, but also has a positive role as an individual, as a nation's citizen, as well as an international citizen. "The school as an educational institution is required to be able to play a role and responsibility to instill and develop good values and help students establish and build their character with good values" (Sudrajat, 2011: 48). The same thing also stated Dwiningrum (2013: 154) that schools have an important role in strengthening the character of the nation's education, the values necessary in contextual character education with the conditions of learners succeed in strengthening the elements of social capital. In addition, local wisdom-based education as one of effort to meet human needs to be intelligent, cultured and dignified as a national education goals (Maryono, 2016: 894). Thus, we can understand the urgency of the implementation of character education as an effort to overcome the problem of morality in our generation.

Law Number 20 Year 2003 on National Education System states that the functions of the national education is to establish the character of a dignified civilization, and the development of capabilities of students for the intellectual life of the nation, develop the potential of students to become individuals who have faith and devoutness towards God, has a commendable character, knowledgeable, skilled, healthy, creative, do not depend on others, and as a citizen who has a high sense of responsibility and democracy. This statement emphasizes that character education is very important in the education sector to create a dignified young generation and has a commendable attitude. National character building efforts had been conducted, however the implementation is not optimal. Therefore, we need the right method to cope with the problem, namely by embedding the character education from an early age.

One of the missions in realizing the vision of the Indonesian nation is to realize the system and the educational climate of national democratic and quality in order to strengthen noble character, creative, innovative, knowledgeable nationality, intelligent, healthy, disciplined, and responsible, skilled and Master of Science and technology in order develop human quality Indonesia (Widiyono, 2013: 231). In this connection, Zuchdi (2009: 56) states that the education system is able to develop person who has commandible character, that is personally and socially ready to entering his world should be the main objective of every educational institution.

Education can not be separated from the culture. The education process is the transformation of the social system of culture from one generation to another in a society (the process of cultural transmission). Meanwhile, the ongoing and evolving culture through education. The education process is a civilizing process, and the process of acculturation is the process of education. Sumaatmadja (2002: 40) states the following about the relationship between education and culture, there are at least key words that "Education is an acculturation (familiarization) institutionalization, transfer, imparting (giving, describe), explain, justify, and directing. Seeing this, we can conclude that between education and culture occurred interconnectedness. When talking about education, the culture also participated in it. There is no culture without education and so are the educational praxis always in the cultural sphere (Ruyadi, 2010: 579).

Kutai Kartanegara has a variety of good local knowledge in the form of tangible or intangible. Some experts clarified that there are five categories of local wisdom: first, the wisdom that such a view of life (philosophy); The second wisdom in the form of social life stance, advice and effort revealed in the form of the proverb, parable, poem poems or folklore (folklore); Third, wisdom in the ceremony or ceremonies; Fourth, wisdom in the form of principles, norms, and rules governing the intangibles become a social system; and fifth, wisdom in the form of habits, behavior in everyday social intercourse (Rashidin, Siregar and Coal, in Afif, Bahri and Saeful, Ed., 2009). One of the local wisdom of this district is Erau tradition. Erau aims to plead (cleaning) of land, forest and water, and as an expression of gratitude to Almighty God for the land that is accepted by citizens. This tradition has been going on for hundreds of years, starting from 1300. The tradition is maintained for hundreds of years have certainly had something that was believed to be kept and maintained by the community until now.

Tradition Erau values espoused and upheld as a source of values and identity to live a life in society for people Kutai Kertanegara. These values can serve as guidelines and guidance for the public life of the Kutai Kertanegara. Each local knowledge possessed an area contains values that form the basis and guidelines for community life. Research by Al Musafiri, Utaya and Komang (2016: 269) suggests that local wisdom Using tribes have a role to reduce the impact of globalization by instilling positive values to youth. Planting these values are based on the values, norms and customs of every region. Planting the noble values of local wisdom is 
expected to produce a good individual characters in adolescents. Susanti (2015: 105) states that the values of local wisdom prevailing in the society is basically not a barrier to progress in the era of globalization, but it becomes a transformational power tremendous in improving the quality of human resources as capital competitive and comparative advantage of a nation, This shows the importance of the values contained in the local wisdom. Therefore, extracting the values of the local culture is a strategic step in the effort to build the nation's character.

Based on the background above, the researchers wanted to assess the relevance of traditional values Erau to the values of character education. This study aims to: (1) determine the values contained in Erau tradition, (2) determine the relevance of traditional values Erau with the values of character education Indonesian nation.

\section{Method}

This research is a qualitative descriptive study carried out ethnographic approach in Tenggarong, Kutai Kertanegara, East Kalimantan. This method utilized to delineate in detail the behavior and actions within the "ethnic" scope that are always related to the historical background of its actions (Fatchan, 2015: 1). With this method the disclosed truth can be proved scientifically.

Research populations were keraton relatives, traditional figures, traditional Erau actors and community leaders. The determination of subjects based on the considerations of they know, and understand the tradition of Erau and the values contained therein. Data collection using observation, interview and documentation techniques. These three techniques are mutually supportive and complementary in meeting the data required in this study. The observations took place from $14^{\text {th }}-29^{\text {th }}$ August 2016 in several locations where traditional Erau rituals were carried out, among them in Mangkurawang, Timbau, Jembayan, Gunung Lipan, Tepian Batu, Kutai Lama and Kutai Kertanegara Palace. Interviews was conducted to explore main research. Documentation is done by reviewing books, magazines, articles, to get data and information relating to the object of research.

Analysis of the data used in this study are: (a) data reduction, (b) the presentation of the data, and (c) conclusion. The validity of the data verification by triangulation. Data reduction is done by selecting, focusing and simplifying the data available in the implementation of the Erau tradition in the field. Presentation of data is a collection of data information related to the subject of research. Furthermore, conclusions are generated through various information generated from data being reinforced with supporting theoretical evidence.

The Method section describes in detail how the study was conducted, including conceptual and operational definitions of the variables used in the study, Different types of studies will rely on different methodologies; however, a complete description of the methods used enables the reader to evaluate the appropriateness of your methods and the reliability and the validity of your results, It also permits experienced investigators to replicate the study, If your manuscript is an update of an ongoing or earlier study and the method has been published in detail elsewhere, you may refer the reader to that source and simply give a brief synopsis of the method in this section.

\section{Results and Discussion}

\subsection{Character Building}

The Character is behaviour, identity, and personality inherent in a person. The Character is also a psychological traits, morals or manners that distinguish one person from another. The Character is personality inherent in a person formed from the internalisation of the various policies (virtues) who believed and used as a basis for perspective, think, act, and to act with regard to the dimensions of psychic and physical. The Character is also a way of thinking and behaving that is characteristic of each individual to live and work in the sphere of family, community and country. Gufron (2010) states that the universal character defined as the value of living together based on the pillars of peace, respect, cooperation, freedom, happiness, honesty, humility, affection, responsibility, simplicity, tolerance, and unity. Someone who has a character that will make it different from the others that characterize kahas of the person.

Character building can be defined as any attempt to do to influence the character of the students. Some experts suggest the notion of character education. Among them Koesoema (2007: 3) states that character education is a form of human activity in which there is an action that is intended to educate the next generation. Character education is essentially educational value (Kirschenbaum, 2000; Golemen, 2001 in Setiawan, 2013: 55) which involves aspects of cognitive, feeling, and action. In its implementation, character education is conducted through a process and time, done gradually so that the values in question can be achieved. This is in line with research by Marhayani (2016: 67) which states that character education in Tengahan society runs gradually and becomes part of the process and stages of life of its people. The values of the character's education are preserved, 
made as a guideline for people's lives at this time and for their successors. Thus, the existence of the values of the character of the current generation remains held by the next generation.

Regarding character building, Lickona (1991) state that character education is an attempt to help someone so that he can understand, pay attention, and do the ethical values that core. Character building is intended as well as the formation of character. Education and character-building effort is inseparable from education and cultivation of moral values to students. The aim is that students become dignified, character in the truest sense, and not just memorized cognitively alone. Furthermore, Lickona stated reasons for the importance of character education is given, namely:

1) The exact method used as a way to ensure learners have a personality that is commendable in them life how to improve academic achievement.

2) The method used to increase the academic achievement of learners.

3) Not all students can shape character elsewhere, therefore, needs an appropriate container in its establishment.

4) Prepare students to be able to be respectful of others and socialize in the lives of a diverse society.

5) Departing from the root problems that have relevance to the moral-social problems that occur in the community.

6) The best preparation to meet the behavior in the workplace. The best way to prepare students to act truthfully in the world of work in the future.

7) As a way of learning the cultural values that are part of the work of civilization.

Character building essentially aims to establish the nation's tough, competitive, high morals, tolerant, worked together, patriotic spirit, developing a dynamic, science and technology-oriented animated by faith and piety to God Almighty based on Pancasila. In order to further strengthen the implementation of character building in the educational unit has identified 18 values derived from religion, Pancasila, culture and Objectives of National Education. The values of these characters are: religious, honesty, tolerance, discipline, hard work, creative, independent, democratic, curiosity, the spirit of nationalism, patriotism, respect for the achievements, friends / communicative, love peace, love reading, caring environment, social care, responsibility (Kemdiknas, 2011: 8).

\subsection{Tradition Values of Erau}

Value is something that gives meaning to life, the reference, the starting point and purpose of life. Value is something that upheld. Value coloring, inspiring and involving mindset and actions of a person. Thus, the value becomes a guideline that is believed by someone in to live their lives. The underlying value of a person's behavior because the value has been embedded in the mindset of someone. In the life of the community, the value can be regarded as "the size of the attitudes and feelings of a person or group associated with the state of good and bad, right wrong or like it or not the object in society." Abdulsyani (2012: 49).

In line with the definition above that the value of the benchmark (standard) social behavior that symbolize good and bad in social life, Huki (in Taufik, 2007: 31) describes the characteristics of social values as follows:

"Values are the construction of society that is created through the interaction, then the value is transmitted from one group to the other group through acculturation, defuse and so on, the value of it is learned, the value that satisfy man and take part in an attempt to meet social needs, values conceptually an abstraction of the elements of the value and variety of objects in society, its value tends to relate to one another so that when there is no harmony will give rise to social problems, the values of the emotions, and the value it can influence personal development in society positive or negative. "

From the characteristics of the value of the above can be explained that the value was created by social and not biological or innate. Therefore, the value must be learned early in families through socialization. Values in society that a collective agreement which is the benchmark in achieving prosperity in civic life. Because of the social values there can be referred to as provisions or ideals of what is considered good in society at large. The socially approved and accepted values form the basis for the actions and behavior both personally and socially as the identity of that society. This is in accordance with Muslimin (2017: 28) which states that aspects of the cultural perspective become the identity of the community and can assist in understanding the function and meaning of the activities undertaken by the community itself.

The values in local wisdom are not the same. The values held may vary from region to region. This is evidenced by the difference in the value of local wisdom in the study of Marhayani (2016: 68) states that local wisdom 
Tengahan, Sendangagung contains values: 1) Religion, 2) Environmental awareness, 3) Social awareness, 4) tolerance, and 5) Responsible. Luardini's research (2016: 7) which states that the traditions of Komunitas Adat Terpencil (KAT) of the Dayak community contain: 1) social values as river communities and forest communities, 2) cultural values as nomadic peoples, 3) God is shown by ritual ceremonies and cultural identities associated with religious purposes. Syamsuddhuha, Kamaruddin, Hanafi, and Rafitang (2014: 1094) which states the values contained in Papaseng local wisdom, Bugis which contains the value: 1) Alempureng/honesty, 2) Reso/hard work, 3) Assitulung-Tulungeng, assiwolompolongeng/gotongroyong, 4) Agettengeng/firmness, 5) Awaraningeng/courage, 6) Sipakatau/mutual respect. Similarly, Wandibba (2005) that Kenyan society has values: 1) Morality, 2) Mutual respect for the property of people, 3) Good leadership, 4) Appreciate marriage.

Local wisdom is believed to be able to be a guideline in community life, a reference in behaving and how to solve life problems. Local wisdom makes people able to understand the surrounding conditions and the environment, contributing to the way of life, knowledge and life strategies in the form of actions undertaken by local communities to respond to various problems and meet their living needs.This is similar to Alfitri and Hambali (2013: 125) which states that the tradition of Tepung Tawar can be a means for conflict resolution that occurs in the people of South Sumatra. In line with Rubngam's research (2014: 227) which states that traditional Isan knowledge which is a series of processes arising from the effects of geography, history and cultural processes mixed with knowledge and experiment. Isan's traditional knowledge is divided into prevention and healing and uses natural, supernatural and spiritual methods. The people of Isan believe in spirits, such as $P i$ Taen and Pi Fa Paya Taen is the most powerful in creating earth, water, wind, fire, world and humanity. Similarly Sundanese culture, like other ethnic groups, has a number of cultural moral values systems that occur in the form of complex ideas, cultural activities or behavioral motivation and or physical creation as Sundanese ethnic culture, which contribute to the ethnic identity of the Sundanese (Suryadi \& Kusnendi, 2016: 469).

Tradition is a custom of hereditary derived from their ancestors that they operate in a society. According Peursen (1993: 11) tradition is translated by inheritance or forwarding norms, customs, rules, treasures. Therefore Peursen (1993: 11) argues that "men that make something with that tradition: the human accept, reject or change it."

Erau is a tradition that takes place in Kutai community. Erau derived from the word "Eroh" which means crowded, noisy, boisterous, happy and full of joy. This traditional event held by the empire or the royal family with the intent and purpose followed by the entire community in the sultanate of Kutai. Sappe and Manuel (2012: 13). Erau tradition was first implemented on the mandi tepian and shower tijak tanah ceremony to shore son state officials Stitch screen, namely Aji Batara Agung Dewa Sakti at the age of 5 years. Having grown and appointed King of Kutai Kertanegara the first (1300-1325 AD) also held traditional ceremonies Erau tradition. Since then the tradition Erau held every case of replacement or crowning of Kings Kutai Kertanegara.

Originally Erau tradition is done for the inauguration/coronation of King/Sultan. However, in its development, this tradition is an expression of gratitude for the harvest of crops are enjoyed by the people. The purpose of this tradition is to memelas (tepong tawar) land, forests and water. According to the trust at that time, this ceremony will bring prosperity and happiness, fields, fields, rivers, and forests become fertile and give abundant results for the people (Sani, 2012:299)

Based on observations and interviews (August 14 to August 29, 2016), Erau as a tradition is a traditional ceremony that consists of a series of rituals that runs sacred, coherent, orderly and interconnected. Every ritual is performed has a meaning/value and purpose. Meaning/value and purpose of these rituals was the one who always kept and maintained by the community that animates the behavior and attitude of society Kutai Kertanegara. Belief in cultural values, it makes reference in the guidelines and social life.

Implementation of the current Erau tradition made cooperation between the various parties involved, namely Sultan Kutai Kertanegara, local governments and communities. The course of this tradition for hundreds of years must contain values that are used as guidelines and reference in the life of local communities so that this tradition be maintained and preserved until today. The values contained in this tradition are as follows:

\section{1) Religious Values}

Erau religious values of tradition is reflected in the implementation of the objectives of this tradition. Tradition Erau implemented as a form of gratitude to Almighty God for results obtained public nature Kutai Kertanegara. Through this tradition people believe that God will give you an abundance of crops, safety and prosperity to the community. Religious values are also reflected in the rituals performed in each of the procession. The belief in the supernatural as they profess belief reflected in the rituals. This was reflected in the ritual menjamu benoa, merangin, beluluh, belimbur and other rituals. 
The belief in the supernatural as they profess belief underlies every procession to be carried out. They believe in the existence of Sanghyang and Kemumulan. They did beluluh, menjamu benoa and merangin procession in order the Sanghyang, Kemumulan maintain ongoing Erau tradition so that it goes well. According to interview with Prince Puger:

'Beluluh is a peak early notification to the Sanghyang, Kemumulan including the occult that Sultan will hold Erau in Kutai Kertanegara, particularly at the Palace of Kutai Kertanegara. Sanghyang, Kemumulan and the supernatural who ere in Chief Benoa (Mangkurawang), in the Central Benoa (in front of Kutai Sultan Kertanegara palace) and in the Benoa Tail (Timbau) were treated with food through the menjamu benoa procession. While merangin was done to invite Sanghyang, Kemumulan and the occult to witness Erau traditional ceremonies.' Prince Puger (Sultan's Kutai Kertanegara relatives )

\section{2) Value Unity}

When tradition Erau implemented, all the people of the kingdom of Kutai Kertanegara will travel to the palace to bring the harvest. Representatives from the entire territory of the palace Kutai Ketanegara present to enliven the tradition. They are united in the leadership of the empire, and shoulder to shoulder in the implementation of these traditions. They will also enliven the artistic activity and dexterity are a form of entertainment in it. Here we can see the sense of unity throughout society Kutai Kertanegara Kingdom. As stated Coordinator of Sacred Kutai Kertanegara Kingdom:

'People from rural comes with oars to follow Erau tradition by bringing the crops that submitted to the Sultan. The representatives form every Kutai Kertanegara territory also attended, thus creating the unity under the rule of Sultan Kutai Kertanegara.' Awang Imaludin (Coordinator of Sacred Kutai Kertanegara Kingdom)

The value of unity in this Erau tradition also stated by Sani (2012: 299) that Erau had a symbolic meaning and philosophy that symbolizes the traditional culture, namely Erau as a sign of gratitude, safety, social justice, cleansing the soul and unity.

\section{3) Value of Cooperation/Cooperativeness}

Implementation Erau tradition can take up now is a form of cooperation between the Kingdom of Kutai Kertanegara, and society. Public participation in this tradition seen from the participation in rituals Erau tradition. Cooperativeness and visible cooperation in preparing equipment and supplies traditions, as well as the willingness of the tribes of the interior as well as other indigenous fellowship came to Sultan Kutai Kertanegara. Mutual corporation embedded and rooted in hundreds of years.

'All the necessary preparations in Erau were done with mutual cooperation, such as making a replica of a dragon and more. All working together, as people have and feel that Erau for us.' Statement of Jaini (community leaders).

It accordance with Jannah (2012: 90), which states that Erau as one of the nation's wealth that will not just disappear. This can be seen with the cooperativeness that since hundreds of years ago was rooted in Erau.

In the current era, the cooperation is also evident in the participating governments in the implementation of Erau tradition. This was implemented as a cultural preservation efforts. The government makes Erau as an annual event in the district. Cooperation between the palace, local governments and community are intertwined causing growing sense of solidarity within society, nation and state.

\section{4) Tolerance Values}

In the tradition established Erau mutual respect between ethnic groups who participated in the ritual tradition. Kutai community's tradition in some rituals performed by the purchase. Belian dance is also a part of the dance of the Dayak tribe. In ritual mengulur naga after a ship carrying the dragon back to Tepian Aji Samarinda Seberang will be greeted rituals and reception Bugis and communities in Kutai Lama. It shows the attachment of Kutai tribal society with the Bugis community. At the time of Erau lasting tradition, will display a variety of local arts and agility competitions followed by various tribes in the district of Kutai Kertanegara. By doing so, will be established tolerance of various tribes and communities.

\section{5) Value of Social Awareness}

In this tradition, the king gave his meal reception to the community as a sign of gratitude to the people for this. People were treated very well during the implementation of the ongoing tradition. This indicates the social concern of the royal leaders of the people. The results of interviews with one of the 'dewa', stated:

'During the Erau tradition, the Sultan will entertain people with a variety of food, as a form of awareness and 
gratitude to the people.' Rahmatiah (dewa)

6) Rewarding Achievement Values and Democracy

In Erau tradition, when begelar ritual the Sultan of Kutai Kertanegara Kingdom will also give awards to anyone who is credited to the Kingdom of Kutai Kertanegara and regions. This shows that the kingdom is very much the achievements of its people. No award is given based on kinship ties with the kingdom, but to anyone who becomes eligible based on merit and achievement. This shows the attitude of the king of Kutai Kertanegara democracy. As statement of Prince Puger:

'On the last night, it was held begelar ritual. It was giving the title as a tribute to the people who contributed to the king that was determined through traditional meetings. The title was determined based on the degree of devotion, skills and services to Kutai Kertanegara.' Prince Puger

\section{7) Work Ethic}

Through ritual menjuluk buah bawal and Dewa menjala appears there about the persistence of the community in the work and make ends meet. This shows the attitude or the value of a high work ethic on Kutai. As statement of Prince Puger:

'Menjuluk buah bawal illustrated that before Sultan gave prosperity, belian persistent earn their living with referring to buah bawal. Dewa menjala illustrated the persistence of people in catching the fish for completing the life needs '. Prince Puger.

The two rituals showed the high work ethic of Kutai. In addition, the ritual begelar given sultan to the people in accordance with the achievements and services to the kingdom, government and society will lead to morale and drive to compete in the achievement for the people of Kutai. Similarly, the ritual belimbur, through this ritual we expected back in net and bring a new spirit in building the region. Of rituals above we can see that the tradition Erau can bring the spirit of the work ethic that should be imparted to the public Kutai Kertanegara.

\section{8) Preservation of Cultural Values}

The cultural heritage consists of two types, namely the cultural heritage objects (material) and immaterial (non-material). Erau tradition is not the object of cultural heritage. However, it will also include other cultural heritage such as dances and cultural objects that are used, such as Sangkoh Piatu, rope Cinde, keris Buritkang, hosting, and other objects. With the implementation of this cultural heritage will be maintained continuity.

'Erau is an intangible cultural heritage objects, but there are elements of other cultures either tangible or not. With the implementation of Erau held every year, it makes the preservation of culture awake so that it can run for hundreds of years. 'Sri Wahyuni (The Head of Culture and Tourism of Kutai Kertanegara).

The consistency of indigenous peoples carrying out cultural traditions affects the sustainability of these traditions, so that cultural preservation is maintained. This is also reinforced by Islamic \& Zelenkovska (2012: 174) research which states that Sadi's "Vefa Baba" spiritual Tekke in Skopje is forced to strengthen the position in society, to open the spiritual dimension and maintain a culture and education. This illustrates that cultural preservation can be maintained with consistent execution of traditions.

\subsection{The Value of Character Building in the Tradition Erau}

The values in the tradition Erau above the positive values that animate the behavior of society. We can see that there is value in the character of that tradition. The value of these characters is very important for the formation of character and identity of the people, especially the younger generation. Therefore, we need to instill the value of character education to the younger generation early on.

The value of characters contained in Erau traditions as follows:

\section{1) Religion}

Religious values is an attitude and submissive behavior in carrying out the teachings of his religion, tolerance to the implementation of other worship and live in harmony with other believers. In every ritual tradition Erau implemented based on adherence to Sanghyang-Sanghyang believed by them. Ritual they did according to the beliefs they hold and to maintain relations with Sanghyang harmonization. Ritual implemented as a manifestation of gratitude to God for crops and begged fertility or safety on land, water, forests to God. Rituals are adjusted in line with the emergence of Islam in the Kutai region. This suggests that the very basis of every religious rites performed in the tradition. It is a guide for people Kutai Kertanegara in implementing the actions and behavior. Religious values are an underlying value of each indigenous region. Those are evidenced by another study in which religious values contained in the indigenous communities Tengahan Sendangagung 
(Marhayani, 2016:68), Trust and ceremony on the tradition Bai-Sri-Su-Kwan in the region of Isan (Pongsiri, Chantachon \& Kiantong: 289), patik dohot uhum in Batak Toba society (Susanti, 2015: 98).

\section{2) Tolerance}

Tolerance is an attitude and action that respects differences of religion, race, ethnicity, opinions, attitudes, and actions of others who are different from themselves. In the tradition of Erau implementation involves several parts therein, including Kutai tribe, Dayak and Bugis. Various tribes involved in this tradition shows that mutual respect has been established therein. Tolerance was also evident in stalling dragon ritual, whereby when the dragon drowned after the delegation was greeted by the Bugis in Samarinda Seberang. From here we can see the establishment of inter-ethnic tolerance and others. The value of this character should be imparted to our young generation, especially we are a multicultural country that has a wide range of tribal, ethnic, cultural and other diversity requires tolerance therein.

Indigenous peoples have the awareness to the importance of coexistence with other communities, so that they maintain the harmony of life with tolerance. It is also found in people Tengahan Sendangagung. Tengahan indigenous peoples have a high tolerance in respect of inter-religion. The majority of moslem and other communities of Indigenous Tengahan still held the belief of ancestral spirits. Moslem community participate in Tunggul Wulung activities as a form of tolerance towards the people who still have faith in the spirit of the ancestors (Marhayani, 2016: 68)

\section{3) Work Hard}

Hard work is a behavior that indicates an earnest effort to overcome various barriers to learning and assignments, as well as completing the task as well as possible. Hard working attitude is reflected in rituals Erau tradition. People trying to meet the needs of life by taking and processing resources provided by nature. It remains they did, even though the king has provided prosperity for their people. This attitude also they show to build the area. In the tradition of Erau, people have the duty and part of each event. People vigorously carry out the duties and obligations imposed upon them. With this attitude it is fitting Kutai Kertanegara region into a thriving area. Erau rituals that reflect this attitude can be seen in the ritual menjuluk buah bawal and dewa menjala.

Hard working becames a character which is owned by indigenous peoples. This attitude regards to their efforts in completing the needs of life and natural challenge. As well as reso attitude that exists in pappaseng tradition, Bugis. Pappaseng traditions convey the message that perseverance and hard work continue to be the beginning of success. Therefore, if you want to be successful should be accompanied with desperation abstinence, patience, and work selflessly and sincerity (Syamhudduha, Kamaruddin, Hanafi, \& Tang, 2016: 1095).

\section{4) Respect for achievement}

Respect for achievements is the attitude and actions that drove him to produce something useful for society, and recognize and respect other people's success. Sultan greatly appreciate the achievements of their peoples. This he embodied in ritual begelar which is a ritual of giving the title bestowed on the people of Kutai Kertanegara achievement and meritorious for the palace and local levels. For those who are meritorious, then given a royal title listed on the name contained in a decree by Sultan Kutai Kertanegara. From here we can see that there is a character value of the achievements that can serve as guidelines for people to behave.

\section{5) Democracy}

Democracy is a way of thinking, acting, and acting the same rights and obligations judging himself and others. This democratic values seen on the rituals of giving the title to the communities where the provision of this title is not based on lineage Kutai Kertanegara palace, but by the achievements of the people and services that have been rendered to the palace and regions. Here we see that the equality of rights and obligations for the whole community. Attitude is important democracy. Jannah (2012: 90) states that Erau contains the philosophy of populism, democracy, is also a philosophy of democracy, is also a philosophy of glory and gratitude to the citizens of society.

\section{6) Social care}

Social care is an attitude and actions have always wanted to help other people and communities in need. During tradition Erau signs of progress, the Sultan will give a dinner to the community. This is implemented as an expression of gratitude sultan to the people, and as a form of social concern him to the people. This was done as an expression of thanks to the sultan, and as a form of his social concern to the people. This value is also reflected in the betepak beras ritual which means that the sultan distributes the produce to the people for the prosperity of his people. 
A caring attitude towards others makes people help each other and work together in their environment. This attitude maintained by indigenous peoples. This is also reflected in Tengahan Sendangagung indigenous peoples. The community cooperate in preparing the Tunggul Wulung ceremony without notice the existing social status (Marhayani, 2016: 68).

From the above explanation, it can be seen that there are some values of the characters in the tradition Erau corresponding to the values of character education Indonesian nation. Thus, we can see the relevance of traditional values Erau the educational values of the character of the Indonesian nation. This we can understand, because basically the values of character education Indonesian nation comes from religion, Pancasila, and culture as well as Indonesian national education goals. Not all traditional values Erau in accordance with the values of character education, but the values contained in this tradition is positive and capable of being used as a source of value for society Kutai Kertanegara guidance. In addition, the values of this culture could be the basis for a solution to the problems that occur in the community. The values that exist in the community directly or indirectly may affect its activity, particularly in order to conform to the norms that exist in the surrounding community.

Cultural values and humanitarian needs to be cultivated and transformed so that it can give birth to a citizen civilized and humane. The value of this character that needs to be imparted to the students early on. Strengthening characters in children of school age are needed to strengthen moral values, character, and personality of the students, especially our nation is being incessantly revolutionizes characters of the nation as part of a mental revolution. This meant that our students become good citizens, has a commendable attitude and characters and dignity.

In the Results section, summarize the collected data and the analysis performed on those data relevant to the discourse that is to follow. Report the data in sufficient detail to justify your conclusions. Mention all relevant results, including those that run counter to expectation; be sure to include small effect sizes (or statistically nonsignificant findings) when theory predicts large (or statistically significant) ones. Do not hide uncomfortable results by omission. Do not include individual scores or raw data with the exception, for example, of single-case designs or illustrative examples. In the spirit of data sharing (encouraged by APA and other professional associations and sometimes required by funding agencies), raw data, including study characteristics and indivldual effect sizes used in a meta -analysis, can be made available on supplemental online archives.

\section{Conclusion}

Education can not be separated from the culture. Culture lasted and developed through a process of education. While education is a process of transformation of the socio-cultural system from regeneration in a society. Culture has an important role in the character development of our youth. From the above explanation can be concluded that: 1) Tradition Erau Kutai Kertanegara contains values that are used as guidelines and reference in the life of local communities so that this tradition be maintained and preserved until today. The values contained in Erau tradition that religious value, the value of unity, the value of cooperation/mutual cooperation, tolerance, social care values, appreciate the value of achievement, democratic values, the value of work ethic and value cultural preservation. 2) The values of tradition Erau have relevance to the values of character education Indonesian nation. The relevance lies in religious values, the values of tolerance, respect values of achievement, democratic values, and the value of social care.

Kurikulum 2013 demanding their character formation of students. To achieve these objectives, currently implemented Character Reinforcement Programe (CRP) in schools developed by the Ministry of Education and Culture. One of the principles of development and implementation of this program, namely the principle of local wisdom. Erau tradition which is the local wisdom Kutai Kertanegara contains character values that have relevance to character education. Utilization Erau tradition in the learning process of Social Sciences has advantages to unlock the value of character for learners in Kutai Kertanegara. Therefore, teachers need to integrate Erau tradition in learning as learning teaching materials of Social Sciences of the goal attainment of character education in the curriculum in 2013 reached. Exploration of other local wisdom need to be developed and integrated in other subjects as teaching materials.

\section{References}

Abdulsyani. (2012). Sosiologi Stematika teori dan Terapan. Jakarta: Bumi Aksara

Alfitri., \& Hambali. (2013). Integration of National Character Education and Social Conflict Resolution through Traditional Culture: A Case Study in South Sumatra Indonesia. Asian Social Science, 9(12). https://doi.org/10.5539/ass.v9n12p125 
Almusafiri, M. R., Utaya, S., \& Astina, I. K. (2016). Integrasi Nilai-Nilai Kearifan Lokal Suku Using Dalam pendidikan Karakter Sekolah Menengah Atas. Retrieved from http://ap.fip.um.ac.id/wp-content/uploads/ 2016/03/19-M.-Rizqon-Al-Musafiri-Sugeng-Utaya-I-Komang-Astina.pdf

Alwasilah, A. C., Suryadi, K., \& Karyono, T. (2009). Etnopedagogi Landasan Praktek Pendidikan dan Pendidikan Guru. Bandung: Kiblat.

Dwiningrum, I. A. S. (2013). Nation's Character Education Based on the Social Capital Theory. Asian Social Science, 9(12). https://doi.org/10.5539/ass.v9n12p144

Fatchan, A. (2015). Metode Penelitian Kualitatif. Yogyakarta: Ombak.

Islam, A., \& Zelenkovska, L.S. (2012). The Islamic Mystical Spiritual Music Tradition in the Era of New Musical Tendencies. Asian Social Science, 8(6). https://doi.org/10.5539/ass.v8n6p170

Jannah, U. (2012). Menelusuri Sejarah Asal Mula Balikpapan Melalui Perayaan Erau Balik Delapan Sebuah Kajian Budaya dan Folklor. Jurnal Premiere Educandum (JPE) P-ISSN: 2088-5350 Vol. 2 No. 1

Koesoema, D. (2007). Pendidikan Karakter. Jakarta: Grasindo.

Lickona, T. (1991). Educating for Character: How Our School Can Teach Respect and Responsibility. New York: Bantam Books.

Luardini, M. A. (2016). Socio-Cultural Values of Traditional Communities: A Case Study of the Dayak in Kalimantan. Asian Culture and History, 8(2). https://doi.org/10.5539/ach.v8n2p1

Marhayani, A. D. (2016). Development of Character Education Based On Local Wisdom in Indegenous People Tengahan Sendangagung. Journal of Education, Teaching and Learning, 1(2), 66-70.

Maryono. (2016). The implementation of schools' policy in the development of the local content curriculum in primary schools in Pacitan, Indonesia. Academic Journals, 11(8), 891-906.

Musanna, Al. (2011). Rasionalitas dan aktualitas Kearifan Lokal Sebagai Basis Pendidikan Karakter. Jurnal Pendidikan dan Kebudayaan, 17(6).

Muslimin, M. (2017). A Traditional Communication of Bugis (Note 1) in the South Sulawesi of Indonesia through the Art Performance of Kecapi. Asian Social Science, 13(3). https://doi.org/10.5539/ass.v13n3p21

Peursen, C. A. V. (1993). Strategi Kebudayaan. Yogyakarta: Kanisius

Pongsiri, R., Chantachon, S., \& Kiantong, N. (2013). Conservation and Promotion Model for Local Wisdom Related to Bai-Sri-Su-Kwan Traditions, Beliefs and Ceremonies in the Isan Region. Asian Social Science, 9(11). https://doi.org/10.5539/ass.v9n11p280

Rachmah, H. (2013). Nilai-Nilai Dalam Pendidikan Karakter Bangsa Yang Berdasarkan Pancasila dan UUD 1945. E-journal Widya Non-Eksakta, 1(1).

Rasyidin, Al., Siregar, Parluhutan., Batubara., \& Khuzaimah. (2009). "Penyerapan Nilai-Nilai Budaya Lokal dalam Kehidupan Beragama di Medan: Studi Tentang Budaya Lokal di Medan” dalam Afif dan Bahri, Saeful. Harmonisasi Agama dan Budaya di Indonesia (2). Jakarta: Balitbang Kemenag.

Rubngam, C., Paengsroy, K., \& Krairach, T. (2014). Integration of Isan Traditional Knowledge in the Holistic Health Treatment of Postpartum Mothers. Asian Culture and History, 6(2). https://doi.org/10.5539/ach.v6n2p227

Ruyadi, Y. (2010). Model Pendidikan Karakter Berbasis Kearifan Budaya Lokal. Proceedings of The 4th International Conference on Teacher Education; Join Conference UPI \& UPSI.

Sani, Y. M. (2012). Erau: Ritual Politik dan Kekuasaan. Jurnal Al-Qalam, 18 (2).

Sappe, M., \& Manuel G.S.R. (2012). The Magic of Erau. Jakarta: Pemda Kutai Kertanegara \& Lionmag.

Setiawan, D. (2013). Peran Pendidikan Karakter Dalam Mengembangkan Kecerdasan Moral. Jurnal Pendidikan Karakter, Tahun III, Nomor 1.

Sudrajat, A. (2011). Mengapa Pendidikan Karakter?. Jurnal Pendidikan Karakter, Tahun I, Nomor 1.

Suparno. (2016). Materi disampaikan dalam Seminar Pendidikan Karakter. Universitas Negeri Yogyakarta.

Suryadi, E., \& Kusnendi. (2016). The Influence of Local Wisdom on the Actualisation of Educative, Scientific and Religious Behaviour on an Academic Environment in a University. American Journal of Applied Sciences, 13(4), 467-476. https://doi.org/10.3844/ajassp.2016.467.476 
Susanti, E. (2015). Nilai-Nilai Budaya Batak Toba Sebagai Sumber Pembelajaran IPS Dan Proses Pengembangan Wawasan Kebangsaan: Studi Naturalistik Inkuiri di MTSn Balige Provinsi Sumatera Utara. Jurnal Indi-Inovasi Didaktif, 1(1).

Syamsudduha, Kamaruddin, Hanafi, H., \& Tang, R. M. (2014). Educational Value and Character in Pappaseng Bugis (Buginese Message). Journal of Language Teaching and Research, 5(5), 1092-1102. https://doi.org/10.4304/jltr.5.5.1092-1102

Taufik, R. D., Tarsisius, W., \& Didi, W. (2007). Sosiologi 1, Suatu Kajian Kehidupan Masyarakat (Sosiologi Kelas $X)$. Jakarta: Yudhistira.

Wandibba. (2003). Kenyan Cultures and Our Values. Wajubu a journal of social and religious concern Vol. 20 No. 4 - December 2005. http://africa.peacelink.org/wajibu/articles/art_4484.html

Widiyono, Y. (2013). Nilai Pendidikan Karakter Tembang Campursari Karya Manthous. Jurnal Pendidikan Karakter. Tahun III, No. 2.

Zuchdi, D. (2009). Pendidikan Karakter, Grand Design dan Nilai-nilai Target. Yogyakarta: UNY Press.

\section{Copyrights}

Copyright for this article is retained by the author(s), with first publication rights granted to the journal.

This is an open-access article distributed under the terms and conditions of the Creative Commons Attribution license (http://creativecommons.org/licenses/by/4.0/). 